\title{
PEASANT FARMS AND ECONOMIC EFFICIENCY IN THE UKRAINIAN SSR IN THE 20S OF THE XX CENTURY
}

\author{
V. V. Olyanich, Doctor of Historical Sciences, Professor of Department of History and Socio- \\ Economic Disciplines, Kharkiv Humanitarian and Pedagogical Academy, Kharkiv, Ukraine \\ L. V. Olyanich, Candidate of Historical Sciences, Associate Professor of Department of History and \\ Socio-Economic Disciplines, Kharkiv Humanitarian and Pedagogical Academy, Kharkiv, Ukraine
} DOI: https://doi.org/10.31435/rsglobal_conf/25012021/7366

\begin{abstract}
The article investigates the economic efficiency of farms in the USSR in the 20's of the twentieth century. Much attention is paid to the study of socio-economic indicators, identifying opportunities to meet production farms and their welfare needs. The author argues that the farms in the USSR in the 20's of the twentieth century were characterized by rather sad indicators of economic efficiency, since a large number of households do not even have available land, livestock, tools and more. On the one hand this is due to the crisis of the early 20's. Caused by the devastating effects of war, revolution, social and economic experiments - nationalization and socialization of land, disruption of grain farming, a situation complicated famine and drought in the south of Ukraine, reducing livestock. On the other hand the socio-economic characteristics and the ability to establish a consumer economy to achieve functional norms to ensure its industrial and social needs in the Marxist paradigm of public relations coverage served only to establish the class structure and definition of objects of taxation, but not for the formation of economically developed farms.
\end{abstract}

Keywords: farm, economic efficiency, production needs, social and domestic needs, peasants.

The aim of the article is to study the economic efficiency, capacity and ability to fulfill the production and own social and household needs of peasant farms in the USSR in the 20s of the twentieth century.

The problem of the article. A study of the economic efficiency of peasant farms in the USSR in the 20 s of the twentieth century is a necessary element in determining the optimal structure of agriculture and its development in Ukraine.

Statistical and archival data, research and periodicals of the 1920s are analyzed.

Presenting of the main material. The literature of the 1920's recorded a class-formative definition of peasant entrepreneurship. In particular, the representatives of the organizational and production business focused mainly on the consumer-labor type of internal functional development of the peasant economy, its optimal size, but did not think of it in terms of entrepreneurship, so did not cover another aspect - economic efficiency production, as well as their own social and household needs. In this regard, in my opinion, the assessment of the production needs of the peasant economy, which was expressed by O. Farba in 1928 in one of the publications [7, p. 54-70] is distinctive. The researcher dared to apply the category of macroeconomics to individual farms. They are investment, production needs, plans to renew the means of production, production volume. Operating with them, he tried to find an answer to the question of the possibility of satisfying the so-called investments by the forces and means of the economy itself. It was important for him not to identify the features of the expanded reproduction of the means of production, but to find out the conditions for the volume of targeted lending to agriculture.

The method proposed by O. Farba had a pragmatic goal. He wanted to identify the creditworthiness of specific farms and the approximate amount for the implementation of social and class credit, however its cognitive capabilities are much deeper and broader. Identifying the organizational and productive capacity of the economy for its own functional needs can serve as a criterion for determining the optimal forms of agricultural entrepreneurship. Signs of marketability and logistics do not exhaust the evaluative characteristics, they are even derived from the organizational and economic optimum.

The conclusions reached by $\mathrm{O}$. Farba have fundamental cognitive significance, although their argumentative and evidentiary base turned out to be insufficiently convincing in some cases. A significant part of "low-strength farms", according to him, did not show social activity on the need to spend on 
production needs, and such among non-sown there were $40 \%$ and $15 \%$ with sowing 1.5 tithes [7, p. 55]. They did not see the prospects and feasibility of production costs, because they did not find economic ground for their rational use. There were so called "risk zone" farms with an allotment of 1.5-2 tithes, which "survived" by renting land, non-agricultural earnings. Their demonstration of "social passivity" to the target loan can be explained by the deliberate action of the owner, who relied on his own strength, refused the loan so as not to spend it on food. Modern researchers Kalinichenko V.V., Morozov A.G. [8], considering this issue, prefer to use new theories and conclusions.

Expenditures were productive and non-productive, so it is important to show their first expenditure item, as simultaneous consideration provides an answer to the question of the purchasing power of the private farm, and this is a slightly different social characteristic. It is essence to determine the priority of the costs from the budget of the peasant's farm for the purchase of equipment, livestock, seeds, equipment in the context of domestic investment for achieving functional and production balance. During the season, the farm could buy a horse or an ox, but would leave itself without a plow, harrows, seeds, etc. The enterprise of the peasant-owner was to maintain the intra-industry balance, and if possible to rent land, increase livestock, buy equipment.

Investigating the "size of investment", which provided the maximum production needs of peasant farms, O. Farba used the term - the limits of reasonable costs in terms of labor economy. These were the amounts of costs that could be covered or achieved by the "business family". For the economy of the grain region the costs amounted to 203 rubles, for beet region - 194 rubles, for the suburban - 269 rubles, which generally did not exceed $20 \%$ of the cost of its means of production [7, p. 56]. The real expenditures of peasant farms are recorded by their seasonal statistical surveys. Thus, in April-May 1926/27, the expenditures of steppe farms were much higher than in June-July, but gradually increased in autumn. The winter and early spring period is characterized by a decline in the expenditure part of the budget of the peasant's farm for material and household needs. The amount of money spent on one farm in Polissya was 373, in Western Ukraine - 422, in Eastern Ukraine - 501, in the Steppe - 607 rubles. [2, p. XVII.] One Polissya farm spent 8.9 and $7.5 \%$ on the purchase of agricultural equipment, in Western Ukraine 7.9 and 9.1\%, respectively, in Eastern Ukraine - 8.8 and $7.2 \%$, in the Steppe -10.3 and $6.5 \%$ of the amount of annual cash income.

On average in Ukraine, the farm wasted about $15 \%$ of the annual amount of production costs for the maintenance and purchase of livestock, and $10 \%$ for livestock. The relatively insignificant percentage of expenditures on these priority items of economic activity is explained by compensation due to the offspring of cattle and artisanal production of basic equipment. Here a peasant-entrepreneur appears, with factory or small shop handicraft equipment. For example, ploughless farms were observed among non-sown or with sowing up to 3 acres, where their share reached $66-98 \%$, but decreased in high land-rich peasant farms. If we take one hundred percent level of plow supply, it applied to farms with allotments of 8-9 acres and more, which can also be attributed to the level of harrow supply, but they lacked horse rakes, mechanical threshers, fans, and other complex agricultural machinery, although there were some farms with allotments from 13 to 30 tithes. Every fourth farm up to 2 tenths had a plow, though there was a need to rent stock or spouse. Almost $40 \%$ of farms did not have tools for plowing and sowing, so they had to rent them, renting out land, went hunting, and planting hayfields. This was the situation in the spring of 1926, but it did not change significantly in the following years. In 1928 there were $40.1 \%$ without tools for plowing and sowing, and 54.6 plows and bookers, 71.1 harrows, 5.5 seeders, 5.9 reapers, 0.6 mowers, 1 ,6, fans 10.2 [4, p. 174].

The absence of a plow or harrow in the peasant economy testified to the insufficient level of their agro-technical support, due to several reasons: the extreme high cost of agricultural machinery, which was inaccessible to some peasants farms; the reverse effect of scarcity of land; the ratio of agricultural and non-agricultural occupations, wholesale cultivation of land. I note that the share of landless farms in the USSR in 1921 was $23.8 \%$, in $1922-30.3 \%$, in $1923-33.8 \%$, in $1924-41.6 \%$ [3, with. 254], i. e. their share increased due to the decline of agricultural production, so this social group, although it had the characteristics of rural private entrepreneurs, worked exclusively for their own support.

Agriculture in the first half of the 1920's experienced a deep crisis due to the devastating effects of wars, revolutions, socio-economic experiments - the nationalization and socialization of land, the disorganization of grain farming. The situation was complicated by famine and drought in southern Ukraine, reducing livestock. Thus, in 1921 there were $19.2 \%$ of farms without working cattle, in $1922-34.1 \%$ of farms, in $1923-45.3 \%$ of farms, in $1924-46.4 \%$ of farms [3, p. 254]. In Volyn in the spring of 1924 there were $37.6 \%$ of farms without working cattle, in Donetsk region - 
$44.9 \%$ of farms, in Ekaterinoslav region - 51.5\% of farms, in Kyiv region - 55.9\% of farms, and $43.6 \%$ of farms in Volyn cultivated their own cattle, $27 \%$ of farms in Donetsk region, $19.5 \%$ of farms in Katerynoslav region, $25.7 \%$ of farms in Kyiv region [5, p. 65]. Almost half of Ukrainian farms did not have working cattle $(46.4 \%)$ and the necessary equipment (41.6\%), so they resorted to those forms of entrepreneurial activity that would provide them with livelihoods.

In the mid-1920s, when the NEP stabilized the economic situation, but in agriculture, if we take the indicator of the availability of working cattle, and it was the main traction force, no significant changes took place. The results of the spring survey of peasant farms in 1926 revealed that in the fourth part of the administrative units of the USSR there were $50-76 \%$ of farms without working cattle $[5, \mathrm{p} .65]$. The supply of oxen to peasant farms was as follows: one ox had no more than $1 \%$, two from $0.2 \%$ to $23.4 \%$ (Luhansk district) [5, p. 65]. Thus, according to the results of the spring survey of 1927, it turned out that in Ukraine in 1926, there were 44.4\% farms without working cattle, in 1927 $42 \%$, ie 2.2 million small farms [6, p. 4].

In 1928 there were $38.8 \%$ of farms without working cattle [6, p. 4], i. e. their share decreased comparing to previous years, but it testified to the lumpenization of the peasantry. For example, in the steppe areas, which had heavy soils - chernozems, there were 355,443 farms without working cattle (35.4\%) [6, p. 2]. A similar situation developed in Eastern Ukraine, and in Western Ukraine in 1928 there were $50.4 \%$ of farms without working cattle. Only in Polissya, where haymaking predominated, the number of farms without working cattle was much smaller compared to other regions $-23.8 \%$.

In historiography, especially Soviet, years of 1921-1925 were considered as a period of agricultural reconstruction, but the real situation indicated the decline of its productive forces. The critical situation of 1921-1923 can be explained by the consequences of war, revolution, drought, and famine, but what can we say about the second half of the 1920s, the so-called "Nepian renaissance"? The NEP had advantages over the policy of military communism, but it did not create the right conditions for the systematic revival of the main branches of agriculture. The party and Soviet authorities reported a steady increase in the number of cattle in Ukraine, but these were general figures. If in 1923 there were 46\%, then in $192644 \%$ of farms without workhorses [1. with. 255], and their presence testified not only to the main traction force - it demonstrated the social status of the small farm, the type of owner. Positive changes took place, but the share of farms without working cattle (horses and oxen) was too large.

Conclusions and prospects for further research. Peasant farms in the USSR in the 1920s were characterized by rather sad indicators of economic efficiency, as a large number of farms did not even have land, livestock, stock, and so on. On the one hand, this is due to the crisis of the early 1920s, caused by the devastating effects of wars, revolutions, socio-economic experiments - nationalization and socialization of lands, disorganization of grain farming. The situation was complicated by famine and drought in southern Ukraine, reducing livestock. On the other hand, socio-economic characteristics and the ability to establish the economy to achieve the consumer-functional norm of its production and sociodomestic needs in the Marxist paradigm of coverage of social relations, with its single-line classformation method of assessing phenomena, served only to establish class structure and determine objects of taxation, and not for the formation of economically developed farms.

\section{REFERENCES}

1. $\mathrm{X}^{\text {th }}$ All-Ukrainian Congress of Soviets of Workers, ' Peasants' and Red Army Deputies, April 6-14, 1927 Kh., 1927

2. Money circulation of the peasant economy of Ukraine for 1926-27 (according to daily records of voluntary correspondents): Statistics № 123. Volume IV. Vip. 4. - H.: CSU USSR, 1928.

3. Results of economic construction of the USSR for 1923-1924 - Kh., 1925.

4. Results of the spring survey of agriculture in Ukraine in 1928 (Selective census of farms): Statistics of Ukraine № 160. Vol. III. Series 2. Agricultural statistics. Issue 15. - H.: CSB USSR, 1929.

5. Results of the spring survey of agriculture in 1924 (sample census of the population of peasant farms): Statistics of Ukraine №59. - H., 1925

6. Results of the spring survey of agriculture in Ukraine in 1927. (Selected census of peasant farms). Statistics of Ukraine № 130. - H., 1928

7. Farba O. Production needs of the peasant economy // Economy of Ukraine. - 1928. - №5.

8. Kalinichenko V. Peasant economy of Ukraine in the period of the NEP: Historical and economic research. Kharkiv: Osnova, 1997.-400 p.

9. Morozov A.G. Village and money: Ukrainian credit cooperation in the days of the NEP: a monograph. Cherkasy, 1993. - 275 p. 